\title{
Morpho-anatomical and Micromorphometrical Evaluations in Soybean Genotypes during Water Stress
}

\author{
Renata Stolf ${ }^{1}$, Moacyr Eurípedes Medri ${ }^{1}$, José Antônio Pimenta ${ }^{1}$, Maria Regina Torres \\ Boeger $^{2}$, Jaqueline Dias ${ }^{1}$, Noélle Giacomini Lemos ${ }^{1}$, Maria Cristina Neves de Oliveira ${ }^{3}$, \\ Rodrigo Luís Brogin ${ }^{3}$, Naoki Yamanaka ${ }^{4}$, Norman Neumaier ${ }^{3}$, José Renato Bouça Farias ${ }^{3}$ \\ and Alexandre Lima Nepomuceno ${ }^{3 *}$ \\ ${ }^{1}$ Departamento de Biologia Animal e Vegetal; Universidade Estadual de Londrina; Rodovia Celso Garcia Cid, \\ PR445, Km380; C. P.: 6001; 86051-990; Londrina - PR - Brasil. ${ }^{2}$ Departamento de Botânica;Universidade Federal \\ do Paraná; Centro Politécnico; C. P.: 19031; 81970-990; Curitiba - PR - Brasil. ${ }^{3}$ Embrapa Soja; Rodovia Carlos \\ Strass, Distrito da Warta; C.P.: 6001; 86001-970; Londrina - PR - Brasil. ${ }^{4} J a p a n$ International Research Center for \\ Agricultural Science;1-1, Ohwashi; Tsukuba,Ibaraki; 305-8686 - Japan
}

\begin{abstract}
In a greenhouse experiment, morpho-anatomical and micromorphometrical analyses of two soybean cultivars, MG/BR46 (Conquista) and BR16-tolerant and sensitive to drought, respectively-were used to study their waterdeficit-tolerance strategies. Drought treatments were applied at reproductive stages from $R_{2}$ to $R_{7}$, where evaluations were conducted at 30 days and 45 days after stress started, respectively. The total length of Conquista plants (shoot + root) was greater than of BR16 plants. Pod dry weight was adversely affected due to the lack of moisture, decreasing productivity even of Conquista plants. Both the cultivars had normal development of root hairs; however, it was observed a decrease in the cortex:central cylinder ratio in BR16 stressed for 30 days, and they also showed similar leaflet thickness and stomata distribution. Differences in drought tolerance observed between the two cultivars seemed to be related to factors other than morphological traits since this species has a short lifecycle.
\end{abstract}

Key words: Anatomy, leguminous, drought and root.

\section{INTRODUCTION}

Plants respond to variations in water levels in the soil through the morphological, anatomical, physiological, biochemical and molecular adjustments (Sant'Anna-Santos et al., 2006 and Wang et al., 2003). Water deficit commonly occurs in commercial production of many crops. It can cause substantial negative effects in plant development, reducing the productivity (Lecoeur and Sinclair, 1996). The level of damage depends on genotype, duration and severity of stress and the developmental stage at which the drought occurs (Santos and Carlesso, 1998).

According to Grant (1992), the development of adaptation mechanisms in plants is influenced by many factors, including atmospheric $\mathrm{CO}_{2}$ level, solar radiation, soil humidity, temperature and atmospheric relative humidity. Plants respond to water deficit in many ways such as decreased leaf area, reduced stomata conductivity, increased leaf senescence, and premature abscission of flowers

\footnotetext{
*Author for correspondence: nepo@cnpso.embrapa.br
} 
and fruit. Furthermore, loss of cell turgidity causes reduction in leaf expansion, consequently reducing the transpiration and assimilates synthesis and translocation (McCree and Fernández 1989; Santos and Carlesso, 1998 and Taiz and Zeiger, 1991).

Morpho-anatomical aspects such as cuticle thickness, number of layers of palisade parenchyma, pubescence and leaf rugosity can decrease the surface area contribute to reduced transpiration and photoinhibition caused by stress (Dias et al., 2007). The total leaf thickness is partially determined by the lenght of the palisade parenchyma cells, and thicker leaves can be more efficient in the use of water (Boeger and Wisniewski, 2002). Thus, leaf thickness can affect the tolerance to water stress (Groom and Lamont, 1997 and Turner, 1994).

Water deficit may promote the expansion of root systems to deeper, more-moist zones in the soil profile. During plant development, root length increases until anthesis, decreasing subsequently; decreased efficiency of water absorption may then be apparent (Pimentel and Rossielo, 1995).

Drought tolerance is one of the most important traits and it has a very complex system to be regulated. However, in soybean, only little is known including molecular works. On the other hand, some works (Casagrade et al., 2001 and Oya et al., 2004) revealed BR16 as a very sensitive and Conquista was tolerant. Hence, the present study aimed to analyze the strategies for tolerating water loss using qualitative and quantitative analyses of plant morpho-anatomical characteristics, comparing cultivars and to verify if only morphoanatomical strategies were efficient in soybean to tolerate moderate water stress.

\section{MATERIAL AND METHODS}

Two soybean genotypes were utilized: Conquista (MG/BR46) and BR16, known to be tolerant and sensitive to drought, respectively, on the basis of studies carried out in the field by Embrapa Soybean, Londrina-PR, Brazil (Casagrande et al., 2001 and Oya et al., 2004). In field conditions, these cultivars have different lifecycle length, whereas light supplementation during the experiment decreased flowering-time difference to two days only.

The plants were divided into two groups: a control group at $15 \%$ gravimetric humidity $(\mathrm{GH})$ (near field capacity) and a stressed group at 5\% of $\mathrm{GH}$ (Casagrande et al., 2001). Each group comprised ten plants of each genotype, sown in 10-L pots with sand and nutrient solution under greenhouse conditions (day $30^{\circ} \mathrm{C} \pm 2^{\circ} \mathrm{C}$; night $22 \pm 2^{\circ} \mathrm{C}$; $\mathrm{RH}$ $40 \% \pm 5 \%$ ) in a completely randomized design. All plants were allowed to develop for 45 days in normal conditions (15\% GH). Moisture stress was initiated by withholding the irrigation, until sand humidity reached 5\%. It took approximately five days, and the control group was kept at $15 \% \mathrm{GH}$ until the conclusion of the experiment (90 days later). Samples for morpho-anatomical analysis were collected at 30 and 45 days after stress initiation, corresponding to $R_{2}$ and $R_{7}$ developmental stage (Fehr and Carviness, 1981), respectively, resulting in four samples: control 30 days (C30), stress treatment at 30 days (T30), control 45 days (C45) and stress treatment at 45 days (T45). The pots contained sand and plants were weighed daily in semi-analytical balance to monitoring sand humidity.

For the morphological studies, the variables analyzed were: root and shoot length, plantcomponent dry weights, relative growth rate (RGR), calculated using the formula lnfDWlniDW/time, where fDW is final dry weight, iDW is initial dry weight and time is the stress time treatment (Ferri, 1985), and leaf area. The anatomical studies were conducted on the segments of the apex of the main root and on median leaflets of the third leaf from the apex. Transverse cuts, $12-\mu \mathrm{m}$ thick, were colored by a combination of aster-blue and basic fuchsine according to Johansen (1940) and Sass (1951) with minor modifications. The histological measurements were conducted using the Image Pro-Plus software, v.4.1 (Media Cybernetics) in an optical microscope (Leica Microsystems) coupled with a digital camera.

Before electronic scanning, leaflet segments of 0.5 $\mathrm{cm}^{2}$ were placed in FAA 50\% (formol: acetic acid: alcohol) and dehydrated in an alcohol series. After the samples were critical-point dried with $\mathrm{CO}_{2}$, they were mounted on a metallic support, fixed with a mix of colorless enamel and graphite, covered with gold under vacuum in Balzers Union FL9496 SCD-030 equipment. Observations were made and images were collected using a scanning electron microscope (JEOL JSM-6360LV) at the Electronic Microscopy Laboratory of the UFPR, Curitiba-PR, Brazil. ANOVA were performed using the SAS program comparing the treatments 
and genotypes. Means were compared using Tukey's test $(\mathrm{p} \leq 0.05)$.

\section{RESULTS}

The root systems of both the cultivars and treatments presented variations in the numbers of protoxylem bundles in terms of triarc, tetrarc and pentarc structures, indicating that it was a feature of the species and not a feature probably induced by the drought. These variations were observed either in control plants or in plants submitted to water deficit (Fig. 1). No cultivar showed rootlength responses to water deficit. However, shoot length was reduced by $18 \%$ and $22 \%$ in Conquista plants exposed to water deficit for 30 days (T30) and for 45 days (T45), respectively (Table 1).
In contrast, BR16 plants did not present such differences in shoot length. Leaf area of Conquista plants, submitted to water deficit for 30 days (T30), was reduced by $28 \%$. Similarly, leaf area of BR 16 was reduced by $38 \%$ by T30 and by $34 \%$ by T45 (Fig. 2).

Conquista plants exposed to T30 had a 30\% decrease in root dry weight; however, at 45 days of treatment, neither cultivar showed a response in root dry weight. Shoot dry weights of Conquista and BR16 plants exposed to water deficit for 45 days (T45) decreased by 37 and 31\%, respectively, relative to their controls (C45). Leaf dry weight was reduced by $28 \%$ in Conquista plants at T30, and at 45 days it was reduced by $50 \%$ in Conquista and by $39 \%$ in BR16. Plant dry weight was reduced only in BR16, by $31 \%$, when exposed to T45 (Table 2).

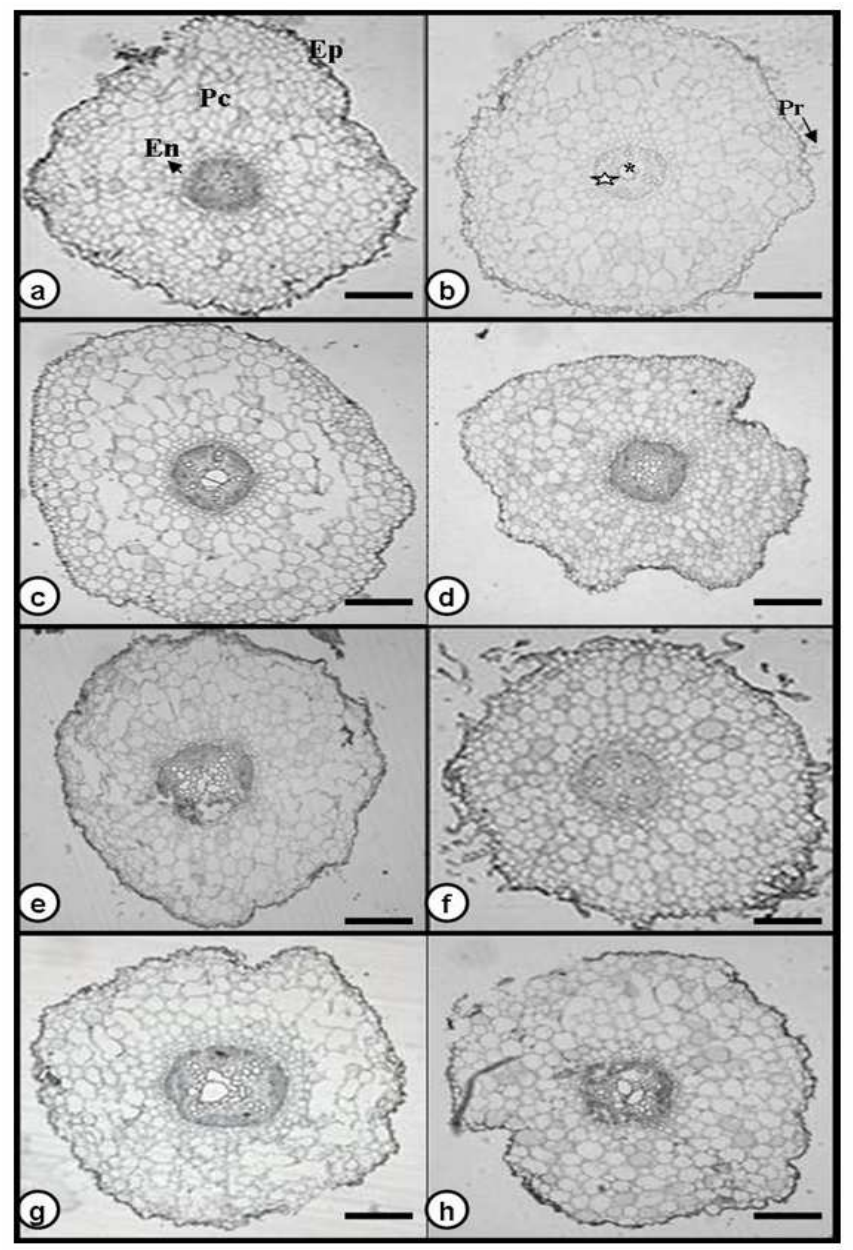

Figure 1 - Transverse sections of the main root of Glycine max: Conquista (C30) (a), Conquista (T30) (b), BR16 (C30) (c), BR16 (T30) (d), Conquista (C45) (e), Conquista (T45) (f), BR16 (C45) (g), and BR16 (T45) (h). En: endodermis, Ep: epidermis, is : protoxylem, *: xylem. Bars $=100 \mu \mathrm{m}$. 
Table 1 - Length of the root, shoot and total length of Glycine max under control condition (C) and subjected to moderate water deficit (T) for 30 and 45 days, of two cultivars: Conquista (drought-tolerant) and BR16 (sensitive). Different letters in a column denote statistical difference between means (Tukey $* * \mathrm{P} \leq 0.05$ ).

\begin{tabular}{lccc}
\hline \multicolumn{1}{c}{ Treatments } & & Lenght $(\mathbf{c m})$ & Total \\
\cline { 2 - 4 } & Root & Shoot & $215.1 \mathrm{~A}$ \\
Conquista (C30) & $35.7 \mathrm{~ns}$ & $179.4 \mathrm{~A}$ & $186 \mathrm{~B}$ \\
Conquista (T30) & 38.3 & $147.7 \mathrm{~B}$ & $199.3 \mathrm{a}$ \\
Conquista (C45) & $41.2 \mathrm{~ns}$ & $168.1 \mathrm{a}$ & $167.5 \mathrm{~b}$ \\
Conquista (T45) & 36.4 & $131.1 \mathrm{~b}$ & $168.6 \mathrm{~ns}$ \\
BR 16 (C30) & $36.9 \mathrm{~ns}$ & $131.7 \mathrm{~ns}$ & 156.6 \\
BR 16 (T30) & 38 & 118.6 & $150.4 \mathrm{~ns}$ \\
BR 16 (C45) & $38.8 \mathrm{~ns}$ & $111,6 \mathrm{~ns}$ & 148.0 \\
BR 16 (T45) & 35.2 & 112.8 & \\
\hline
\end{tabular}

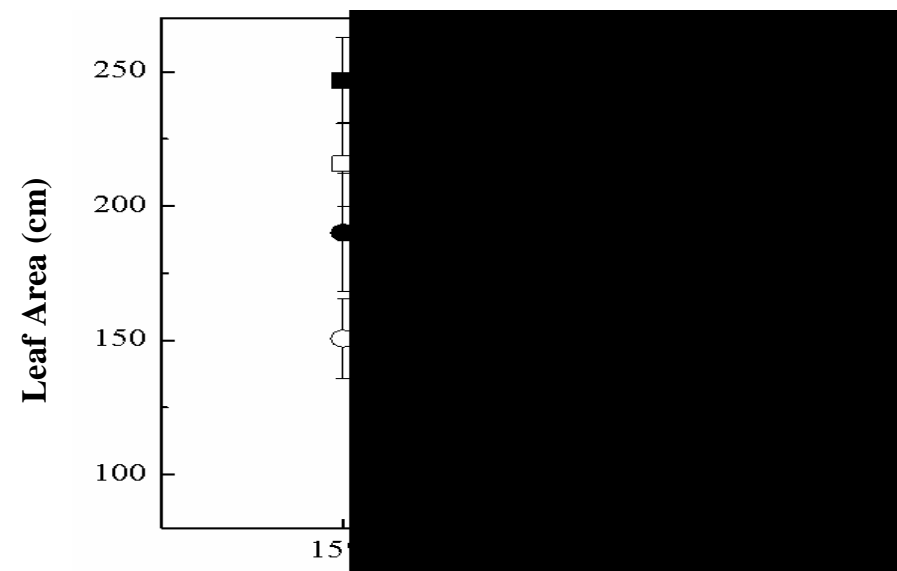

Gravimetric Humidity (\%)

Figure 2 - Leaf area of Glycine max under control condition and moderate water deficit for 30 and 45 days, of two cultivars: Conquista (drought-tolerant) and BR16 (sensitive). Coincident standard error bars denote no difference between means (Tukey, $\mathrm{p} \leq 0.05$ ).

Table 2 - Dry weight of roots and shoots of two Glycine max cultivars: Conquista (drought-tolerant) and BR16 (sensitive) under control (C) and moderate water deficit (T) for 30 and 45 days of treatment. Different letters in a column denote statistical difference between means (Tukey $* * \mathrm{P} \leq 0.05$ ).

\begin{tabular}{lcccccc}
\hline Treatments & \multicolumn{7}{c}{ Dry Weight $(\mathbf{g})$} \\
\cline { 2 - 7 } & Root & Shoot & Leaf & Pod & Total & R/S \\
\hline Conquista (C30) & $7.11 \mathrm{~A}$ & $6.66 \mathrm{~ns}^{*}$ & $9.89 \mathrm{~A}$ & $3.5 \mathrm{~ns}$ & $27.2 \mathrm{~ns}$ & $0.45 \mathrm{~ns}$ \\
Conquista (T30) & $5.01 \mathrm{~B}$ & 5.83 & $7.10 \mathrm{~B}$ & 3.65 & 21.6 & 0.40 \\
Conquista (C45) & $4.23 \mathrm{~ns}$ & $9.08 \mathrm{a}$ & $12.1 \mathrm{a}$ & $8.38 \mathrm{~ns}$ & $33.7 \mathrm{a}$ & $0.20 \mathrm{~ns}$ \\
Conquista (T45) & 3.26 & $5.76 \mathrm{~b}$ & $6.14 \mathrm{~b}$ & 6.71 & $21.9 \mathrm{~b}$ & 0.28 \\
BR 16 (C30) & $5.34 \mathrm{~ns}$ & $4.74 \mathrm{~ns}$ & $7.38 \mathrm{~ns}$ & $4.64 \mathrm{~ns}$ & $22.1 \mathrm{~ns}$ & $.43 \mathrm{~ns}$ \\
BR 16 (T30 & 8.11 & 4.75 & 6.45 & 4.9 & 24.2 & 0.72 \\
BR 16 (C45) & $4.36 \mathrm{~ns}$ & $5.15 \mathrm{a}$ & $6.63 \mathrm{a}$ & $10.1 \mathrm{a}$ & $26.3 \mathrm{a}$ & $0.36 \mathrm{~ns}$ \\
BR 16 (T45) & 2.39 & $3.59 \mathrm{~b}$ & $4.02 \mathrm{~b}$ & $6.96 \mathrm{~b}$ & $16.8 \mathrm{~b}$ & 0.32 \\
\hline
\end{tabular}


Leaf relative growth rate (LRGR) was reduced by 37 and $60 \%$ in Conquista subjected to water deficit for 30 days (T30) and for 45 days (T45), respectively. BR16 plants had an LRGR reduction only after 45 days, by $83 \%$ reduction. Total relative growth rate (TRGR) was reduced only in Conquista, by $17 \%$ with T30 and by $28 \%$ with T45 (data computed from Table 2) (Table 3). For root: shoot ratio, no differences were observed in terms of treatment or cultivar.

Table 3 - Histological measurements of Glycine max root, under control condition (C) and moderate water deficit (T) for 30 and 45 days of treatment, of two cultivars: Conquista (drought-tolerant) and BR16 (sensitive). Different letters in a column denote statistical difference between means (Tukey ** $\mathrm{P} \leq 0.05$ ).

\begin{tabular}{ccc}
\hline Treatments & \multicolumn{2}{c}{ Cortex/Central Cylinder Ratio } \\
\hline & Conquista & BR 16 \\
C30 & $15.4 \mathrm{~ns}$ & $15.6 \mathrm{~A}$ \\
T30 & 16.3 & $13.2 \mathrm{~B}$ \\
C45 & $9.61 \mathrm{~ns}$ & $11.1 \mathrm{~ns}$ \\
T45 & 11.7 & 11.7 \\
\hline
\end{tabular}

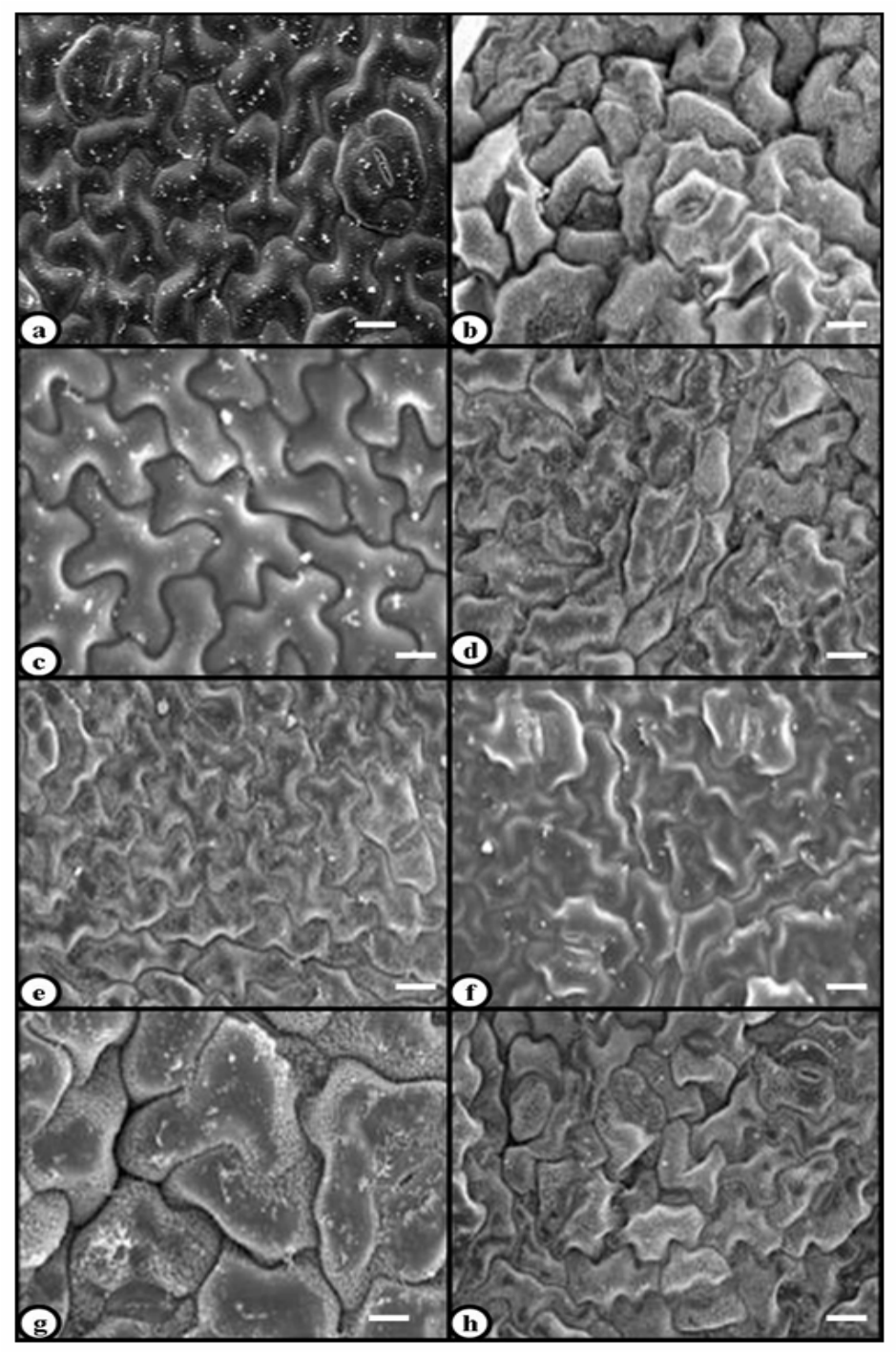

Figure 3 - Scanning electron micrographs of epidermis of Glycine max leaflets of cultivar Conquista: adaxial (C30) (a); abaxial (C45) (b); adaxial (T45) (c); abaxial (T45) (d). Cultivar BR 16: adaxial (C45) (e); abaxial (C45) (f), Bars $=20 \mu \mathrm{m}$; adaxial (T45) (g), Bar $=10 \mu \mathrm{m}$; adaxial (T45) (h), Bar $=20 \mu \mathrm{m}$. Ce: epidermal cells. Es: stomata 
The cortex:central cylinder ratio showed no effects of drought stress in Conquista (T30 or T45). In contrast, BR16 plants, subjected to water deficit for 30 days presented a $16 \%$ smaller ratio. However, after 45 days of water deficit, this cultivar did not show a difference in this variable (Table 4). The epidermis of leaflets in both the cultivars was constituted by a unique layer of cells with periclines and anticlines. The stomata were predominantly paracytic (Figs. 3 and 4). Occasionally, Conquista plants submitted to water deficit showed closed ostioles whereas moisturestressed BR16 plants invariably had open ostioles. Soybean mesophyll is dorsiventral, with biseriate palisade parenchyma and extended cells in many sizes, disposed perpendicularly to the limbo surface. The spongy parenchyma had two or three layers of irregular cells, with prevalent intercellular spaces (Fig. 5). Comparative analysis of leaflet tissue thickness did not reveal differences between the treatments in either of the cultivars analyzed (Table 5). The leaflet central nervure presented xylem in the central portion with external phloem, confirming the organization of the vascular system of dicotyledonous, and a thin layer of sclerenchyma under the phloem. No significant differences were observed in the relative amounts or quantities of these tissues between the treatments or cultivars (Fig. 6). Trichomes were observed on leaves of both soybean genotypes. However no visual differences among the treatments were observed (Fig. 7).

Table 4 - Histological measurements of leaflets of Glycine max in the control condition (C) and with moderate water deficit $(\mathrm{T})$ for 30 and 45 days of treatment, of two cultivars: Conquista (drought-tolerant) and BR16 (sensitive). Different letters in a column denote statistical difference between means (Tukey **P $\leq 0.05$ ).

\begin{tabular}{lccccc}
\hline \multicolumn{5}{c}{ Thickness $(\boldsymbol{\mu m})$} \\
\hline Treatments & $\begin{array}{c}\text { Adaxial surface } \\
\text { of epidermis }\end{array}$ & $\begin{array}{c}\text { Palisade } \\
\text { Parenchyma }\end{array}$ & $\begin{array}{c}\text { Spongy } \\
\text { Parenchyma }\end{array}$ & $\begin{array}{c}\text { Abaxial surface } \\
\text { of epidermis }\end{array}$ & Leaflet \\
\hline Conquista (C30) & $14.7 \mathrm{~ns}$ & $65.0 \mathrm{~ns}$ & $41.8 \mathrm{~ns}$ & $13.3 \mathrm{~ns}$ & $135.0 \mathrm{~ns}$ \\
Conquista (T30) & 14.6 & 64.3 & 52.1 & 14.6 & 145.7 \\
Conquista (C45) & $13.2 \mathrm{~ns}$ & $51.2 \mathrm{~ns}$ & $40.5 \mathrm{~ns}$ & $14.2 \mathrm{~s}$ & $118.7 \mathrm{~ns}$ \\
Conquista (T45) & 12.7 & 57.7 & 43.2 & 12.3 & 126.0 \\
BR 16 (C30) & $14.1 \mathrm{~ns}$ & $63.4 \mathrm{~ns}$ & $41.2 \mathrm{~ns}$ & $15.8 \mathrm{~ns}$ & $134.5 \mathrm{~ns}$ \\
BR 16 (T30) & 15.0 & 62.7 & 38.0 & 16.1 & 131.8 \\
BR 16 (C45) & $13.2 \mathrm{~ns}$ & $55.8 \mathrm{~ns}$ & $39.7 \mathrm{~ns}$ & $13.7 \mathrm{~ns}$ & $122.5 \mathrm{~ns}$ \\
BR 16 (T45) & 12.8 & 61.1 & 33.1 & 14.5 & 121.6 \\
\hline
\end{tabular}

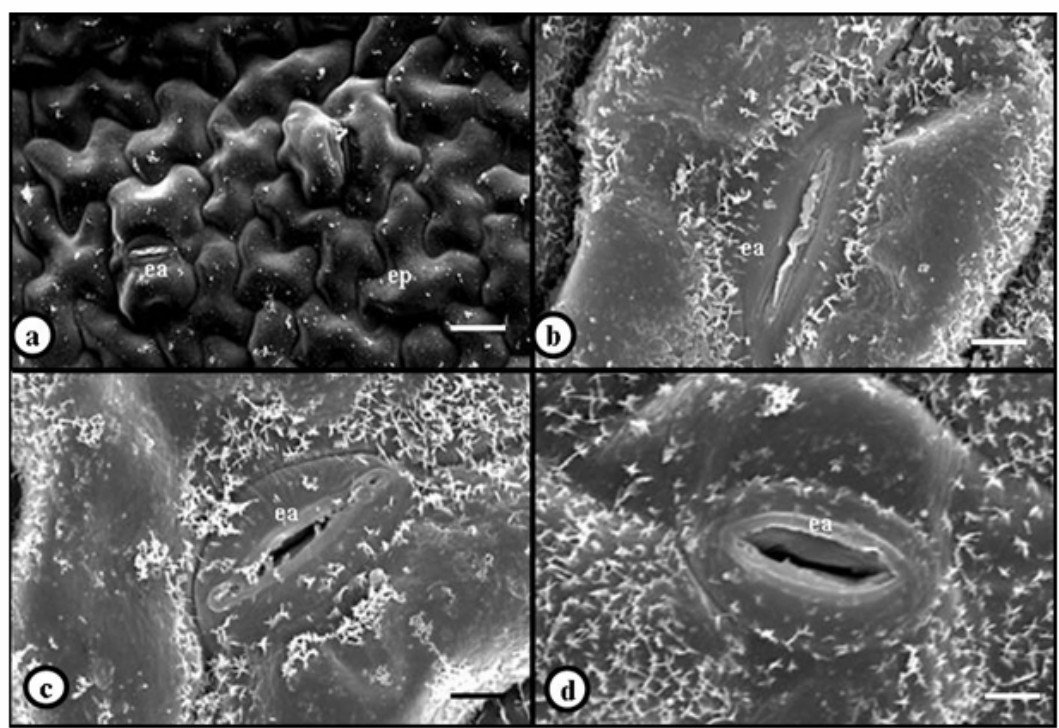

Figure 4 - Scanning electron micrographs of leaflet epidermis of Glycine max with stomata in the cultivars: Conquista (C30) (a), Conquista (T45) (b); BR16 (C45) (c), BR16 (T45) (d). Ea: stomata antechamber. Ep: epidermis. Bars $=20 \mu \mathrm{m}$ (a) and $5 \mu \mathrm{m}$ (b-d). 
Table 5 - Relative growth rates of root, shoot, leaf and total and root: shoot ratio of Glycine max in the control condition (C) and to moderate water deficit (T) for 30 and 45 days, of two cultivars: Conquista (drought-tolerant) and BR16 (sensible). Different letters in the column denote statistical difference between means (Tukey **P $\leq 0.05$ ).

\begin{tabular}{|c|c|c|c|c|c|}
\hline \multirow[t]{2}{*}{ Treatments } & \multicolumn{4}{|c|}{ RGR(mg g-1 day -1)* } & \multirow[b]{2}{*}{$\mathbf{R} / \mathbf{S}$} \\
\hline & Root & Shoot & Leaf & Total Plant & \\
\hline Conquista (C30) & $0.06 \mathrm{~A}$ & $0.04 \mathrm{~ns}^{* *}$ & $0.03 \mathrm{~A}$ & $0.04 \mathrm{~A}$ & $0.45 \mathrm{~ns}$ \\
\hline Conquista (T30) & $0.04 \mathrm{~B}$ & 0.04 & $0.02 \mathrm{~B}$ & $0.04 \mathrm{~B}$ & 0.39 \\
\hline Conquista (C45) & $0.03 \mathrm{~ns}$ & $0.03 \mathrm{a}$ & $0.02 \mathrm{a}$ & $0.03 \mathrm{~A}$ & $0.20 \mathrm{~ns}$ \\
\hline Conquista (T45) & 0.02 & $0.02 \mathrm{~b}$ & $0.01 b$ & $0.02 \mathrm{~B}$ & 0.28 \\
\hline BR $16(C 30)$ & $0.04 \mathrm{~ns}$ & $0.03 \mathrm{~ns}$ & $0.02 \mathrm{~ns}$ & $0.04 \mathrm{~ns}$ & $0.43 \mathrm{~ns}$ \\
\hline BR 16 (T30) & 0.05 & 0.03 & 0.02 & 0.04 & 0.71 \\
\hline BR 16 (C45) & $0.02 \mathrm{~ns}$ & $0.02 \mathrm{a}$ & $0.01 \mathrm{a}$ & $0.03 \mathrm{~ns}$ & $0.36 \mathrm{~ns}$ \\
\hline BR 16 (T45) & 0.01 & $0.02 b$ & $0.002 b$ & 0.02 & 0.32 \\
\hline
\end{tabular}

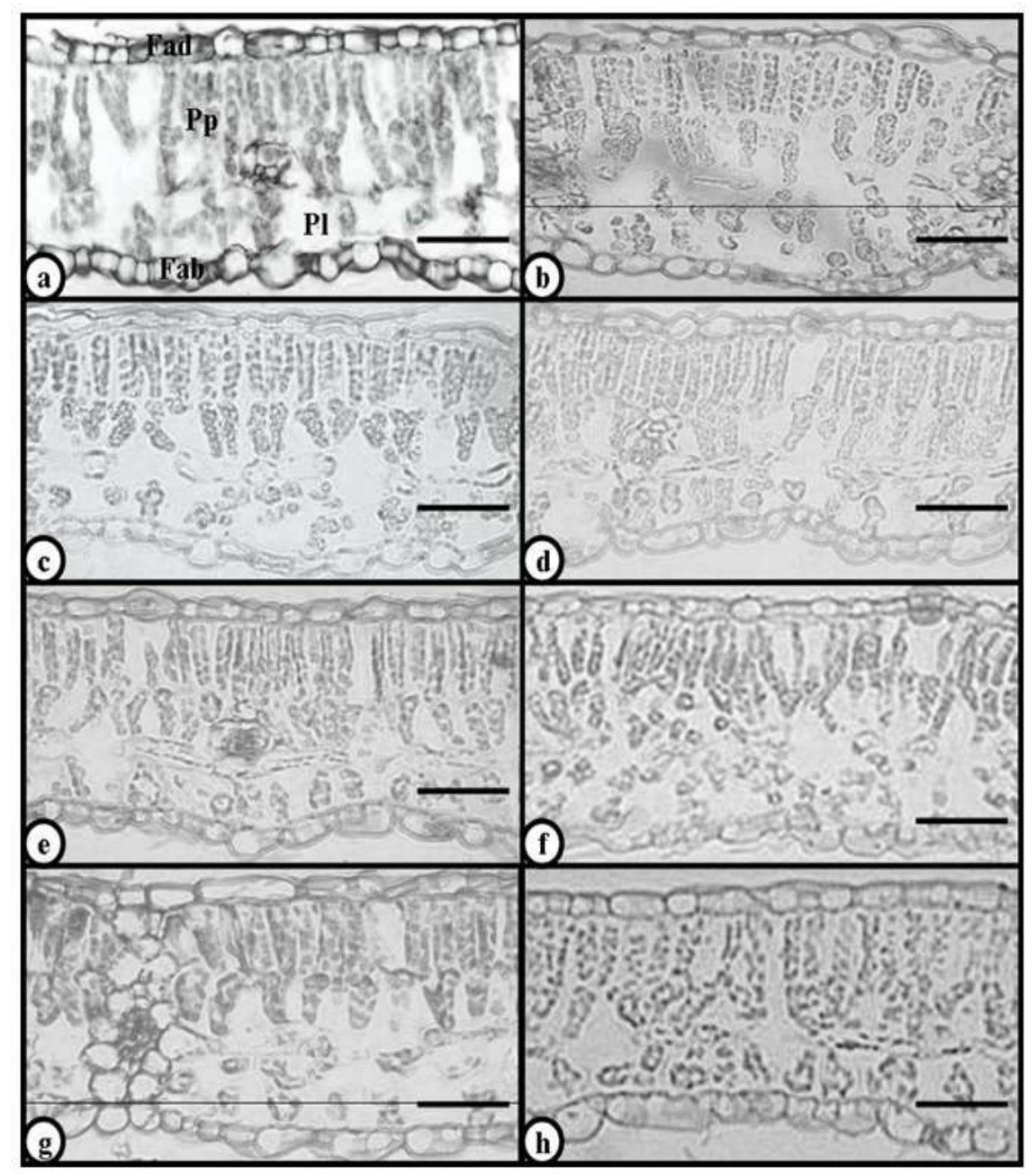

Figure 5 - Transverse section of Glycine max leaflets: Conquista (C30) (a), Conquista (T30) (b), BR16 (C30) (c), BR16 (T30) (d), Conquista (C45) (e), Conquista (T45) (f); BR16 (C45) (g), BR16 (T45) (h). Es: Stomata. Fab: abaxial face of epidermis. Fad: adaxial face of epidermis. Pl: spongy parenchyma. Pp: palisade parenchyma. Bars $=100 \mu \mathrm{m}$. 


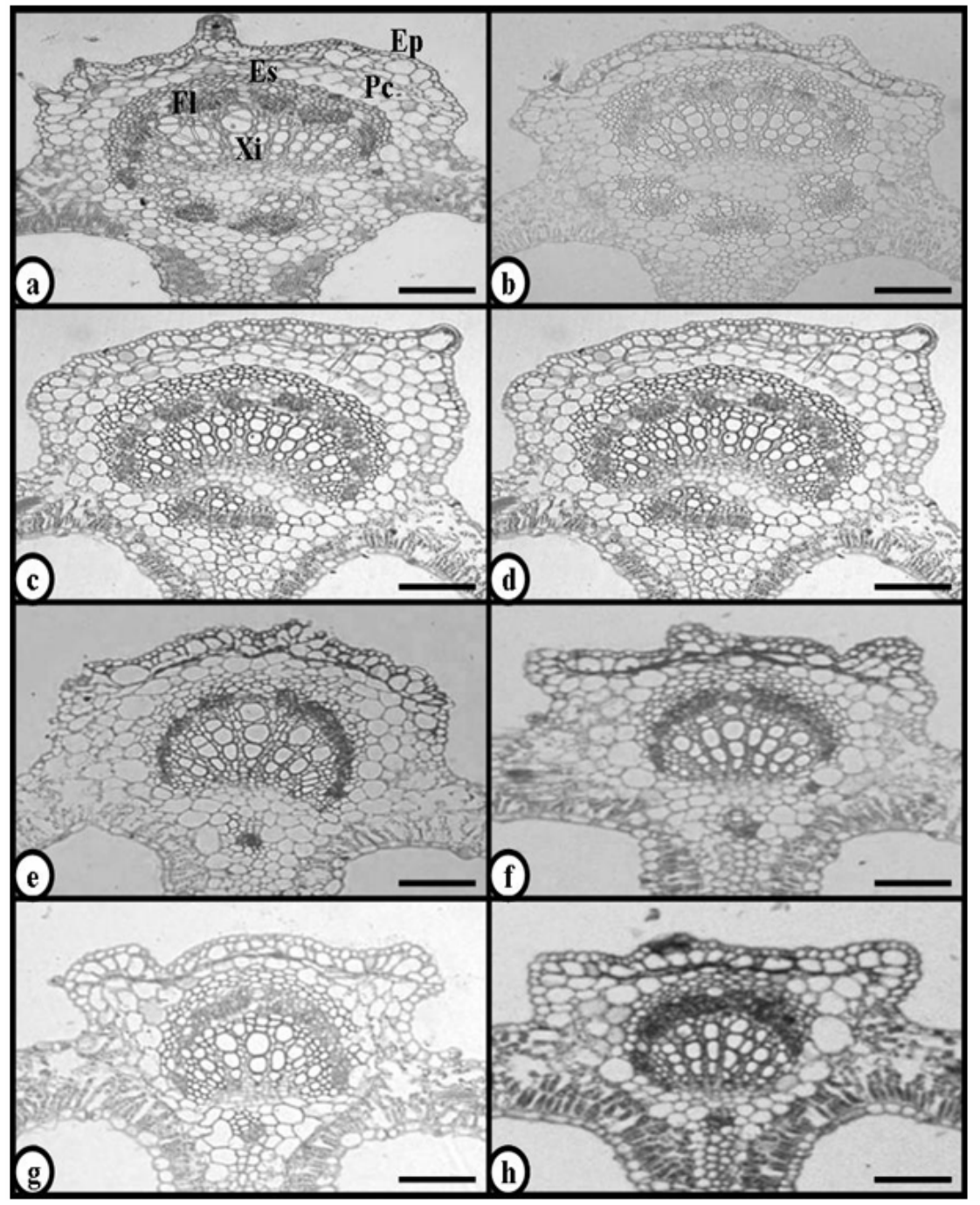

Figure 6 - Transversal section of Glycine max leaflet nervure of Conquista (C30) (a), Conquista (T30) (b), BR16 (C30) (c), BR16 (T30) (d), Conquista (C45) (e), Conquista (T45) (f), BR16 (C45) (g) ad BR16 (T45) (h). Pc: cortical parenchyma, Ep: Epidermis, Es: Sclerenchyma, Fl: Phloem e Xi: Xylem. Bars $=100 \mu \mathrm{m}$.

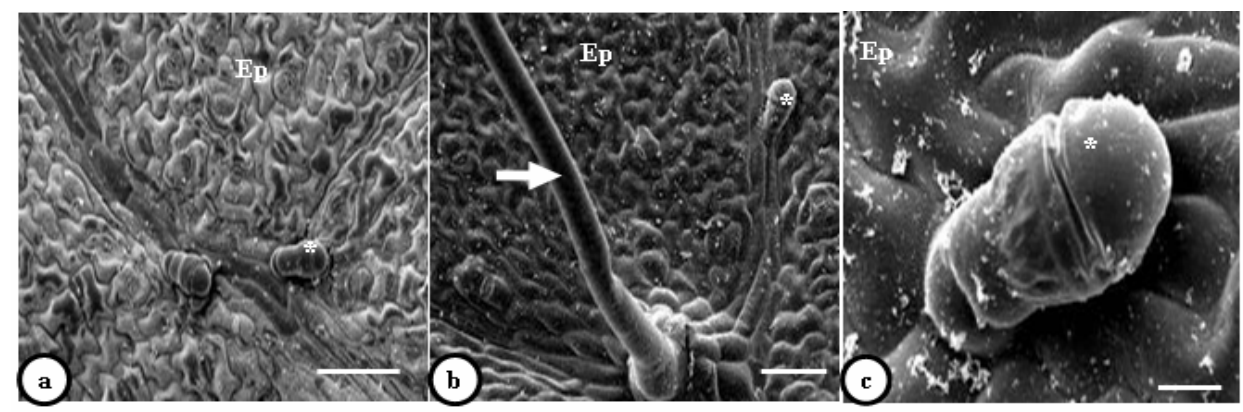

Figure 7 - Scanning electron micrographs of leaflet epidermis of Glycine max with glandular trichomes in detail, in the cultivars: BR16 (T30) (a), Conquista (C30) (b), Bars $=50$ $\mu \mathrm{m}$; Conquista (T30) (c), Bar $=10 \mu \mathrm{m}$. Ep: epidermis, *: glandular trichomes and arrow: trichome. 


\section{DISCUSSION}

The experiment was conducted with sand-cultured plants in the pots, which explained why no significant root-length differences were observed as a result of moisture stress. In field experiments, soybean cultivars characterized as drought tolerant usually showed large quantities of diageotropic roots in the superficial layers of soil (Hudak and Patterson, 1996). Hirasawa et al. (1994) also observed that drought tolerant soybean subjected to moisture stress before flowering developed more-extensive root networks that correlated with higher yields when compared with sensitive genotypes.

The length (shoot+root) of plants submitted to water deficit was greater for Conquista, which were $10 \mathrm{~cm}$ higher than BR16 plants, confirming Casagrande et al. (2001) results. It probably happened because Conquista was more tolerant in relation to BR16 plants having a better response to low available water. Leaf abscission occurred during the period of water deficit, which contributed to the reduction of leaf area in both the cultivars. The drought effects on leaf area and abscission could be a reflection of leaf-nutrient deficiencies. Reduction in leaf area constituted a defense strategy to minimize the water loss (Begg and Turner, 1976; Lawlor, 1993; Mansfield and Davies, 1985) and could be viewed as a xeromorphic characteristic (Brüning, 1973); Lleras, 1977 and Turner, 1994). According to Boeger and Wisniewski (2002), leaf area is regulated by the balance between the carbon gain and water lost.

Dry weight was significantly affected in BR16 plants submitted to water deficit for 45 days, although no difference was observed at 30 days. This could be related to the growth phase in which the stress occurred. At the 30th day of stress, plants were at the $R_{2}$ developmental stage when vegetative and reproductive development occured simultaneously, and because of that, carbohydrate production and translocation usually were at their peak (Fehr and Caviness, 1981). Consequently, larger differences won show up among treatments only after this period. As these pods developed further, less carbohydrate was translocated. If a drought event occurs, translocation is reduced even more. Capacity to retain higher rates of translocation during periods of water deficit could be one of the reasons Conquista had higher dry weights at both sampling dates. Oya et al. (2004) reported lower yields of BR16 in relation to other cultivars in the field, confirming its sensitivity to drought. Reduction of root relative grown rate (RRGR) in Conquista plants submitted to water deficit for 30 days (Table 3) could be due to a decrease in the production of new roots, or due to root death. Conquista is well known to develop a relatively more-extensive root system. However, the $22 \%$ reduction observed could be caused by the limitations imposed by pot volume, inducing a plant-signaled reduction in root growth. The decrease in leaf relative growth rate (LRGR) of both the cultivars was a result of abscission and small production of new leaves. The RGR expresses plant development as a function of dry weight accumulation over time (Ferri, 1985). According to Chiariello et al. (1991), the RGR is a physiological index appropriate for comparison of agronomic traits effects, because it is relative rather than absolute.

Regarding the decrease in the cortex:central cylinder ratio observed in both the cultivars under water deficit Vasellati et al. (2001) showed that drought increased the number of root hairs and decreased the diameter of the metaxylem bundle in Paspalum dilatatum, a common characteristic of plants submitted to drought that could cause a reduction in the cortex:central cylinder ratio.

Trichomes observed on the leaves of both soybean genotypes, were barriers to air movement, consequently decreasing water loss from the leaf surface (Mauseth, 1988). In the present work was observed stomata in the epidermis on both surfaces of the leaf. According to Mott et al. (1982), amphistomatic leaves have a potentially higher capacity for carbon dioxide capture and could achieve elevated levels of photosynthesis, if conditions were suitable.

Glycine max and other species use many strategies to optimize the utilization of water in dry environments and during periods of moisture shortage. Some of these adaptations are anatomical and constitutive; others are transient. Differences between these two cultivars observed previously in the experimental and field conditions were not related to anatomical characteristics according to the present results. Probably, it occurred via physiological and metabolic mechanisms. Furthermore, stress was applied during reproductive growth, $\left(\mathrm{R}_{2}\right.$ to $\left.\mathrm{R}_{7}\right)$, the most-sensitive phase. At this stage, all basic organs and tissues were already formed, thus adaptive morphological modifications could represent disadvantage in 
relation to the metabolic and physiological modifications. Certainly, molecular and physiological mechanisms are in place to differentiate these two genotypes (Bray, 2004).

\section{ACKNOWLEDGMENTS}

The authors thank the financial support provided by PROAP/CAPES and Embrapa Soybean.

\section{RESUMO}

Análises morfo-anatômicas e micromorfométricas de duas cultivares de soja, MG/BR46 (Conquista) e BR16-tolerante e sensível à seca, respectivamente, em experimento conduzido em casa de vegetação-foram feitas para estudar as diferentes estratégias de tolerância ao déficit hídrico. Tratamentos de seca foram aplicados no estádio reprodutivo $\mathrm{R}_{2}$ e $\mathrm{R}_{7}$, onde avaliações foram conduzidas em 30 dias e 45 dias após o inicio do estresse, respectivamente. $\mathrm{O}$ comprimento total das plantas da cultivar Conquista (parte aérea e raiz) foi maior do que das plantas da cultivar BR16. A massa seca da vagem foi adversamente afetada pelo déficit hídrico, diminuindo a produtividade das plantas da cultivar Conquista. Ambas as cultivares tiveram o desenvolvimento de pêlos radiciais normais e, uma diminuição da razão córtex:cilindro central foi observada em BR16 estressada por 30 dias, além de apresentar uma espessura do folíolo e distribuição dos estômatos normais. Diferenças na tolerância à seca observada entre as duas cultivares devem estar relacionadas também a outros fatores, alm das características morfológicas, já que esta espécie possui um ciclo de vida curto.

\section{REFERENCES}

Begg, J.E., Turner, N.C. (1976). Crop water deficits. Advances in Agronomy. 28: 161-217.

Boeger, M.R., Wisniewski, C. (2002). Estrutura e teores de nutrientes foliares de seis espécies arbóreas ao longo de um gradiente sucessional da planície litorânea do estado do Paraná, Brasil. Iheringia. Série Botânica. 57(2): 243-262.

Bray, E.A. (2004). Genes commonly regulated by water-deficit stress in Arabidopsis thaliana. Journal of Experimental Botany. 55(407): 2331-2341.
Brüning, E.F. (1973). Species richness and stand diversity in relation to site and succession of forest in Sarawak and Brunei. Amazoniana. 4(3): 293-320.

Casagrande, E.C., Farias, J.R.B., Neumaier, N., Oya, T., Pedroso, J., Martins, P.K., Breton, M.C., Nepomuceno, A.L. (2001). Expressão gênica diferencial durante déficit hídrico em soja. Revista Brasileira de Fisiologia Vegetal. 12(2): 168-184.

Chiariello, N.R., Mooney, H.A., Williams, K. (1991). Growth, carbon allocation and cost of plants tissues. Plant physiological ecology. Chapman and Hall, New York: P. 328-365.

Dias, J., Pimenta, J.A., Medri, M.E., Boeger, M.R.T., Freitas, C.T. (2007). Physiological aspects of sun and shade leaves of Lithraea molleoides (Vell.) Engl. (Anacardiaceae). Brazilian Archieves of Biology and Technology. 50(1): 91-99.

Fehr, W.R., Caviness, C.E. (1981). Stage of soybean development. Ames: Iowa State University, 12p. (Iowa Cooperative Extensive Service. Special Report, 80).

Ferri, M.G. (1985). Fisiologia Vegetal 1. Editora Pedagógica e Universitária Ltda. $2^{\mathrm{a}}$ ed.: São Paulo.

Grant, R.F. (1992). Interaction between carbon dioxide and water deficits affecting canopy photosynthesis: simulation a testing. Crop Science. 32: 1322-1328.

Groom, P.K., Lamont, B.B. (1997). Xerophytic implications of increased sclerophylly: interactions with water and light in Hakea psilorrhyncha seedlings. New Phytologist. 136: 231-237.

Hirasawa, T., Tanaka, K., Miyamoto, D., Takei, M., Ishihara, K. (1994). Effects of pre-flowering soil moisture deficits on dry matter production and ecophysiological characteristics in soybean plants under drought conditions during grain filling. Jpn. Journal Crop Science. 63: 721-730.

Hudak, C.M., Patterson, R.P. (1996). Root distribution and soil moisture depletion pattern of a droughtresistant soybean plant introduction. Agronomy Journal. 88:478-485.

Johansen, D.A. (1940). Plant microtechnique. New York, McGraw-Hill. 523p.

Lawlor, D.W. (1993). Photosynthesis: Molecular, Physiological and Environmental Processes. Second Edition. Longman Scientific and Technical.

Lecoeur, J., Sinclair, R.T. (1996). Field pea transpiration and leaf growth in response to soil water deficits. Crop Science. 36: 331-335.

Lleras, E. (1977). Differences in stomatal number per unit area within the same species under different micro-environmental conditions: a working hypothesis. Acta Amazonica. 8(3): 473-476.

Mansfield, T.A., Davies, W.J., (1985). Mechanisms for leaf control of gas exchange. BioScience. 35(3): 158164.

Mauseth, J.D. (1988). Plant anatomy. Menlo Park: Benjamin Cummings, 560p. 
McCREE, K.J., FERNÁNDEZ, C.J. (1989). Simulation model for studying physiological water responses of whole plants. Crop Science. 29: 353-360.

Mott, K.A., Gibson, A.C., O'leary, J.W. (1982). The adaptative significance of amphistomatic leaves. Plant Cell Environment. 5(6): 455-460.

Oya, T., Nepomuceno, A.L., Neumaier, N., Farias, J.R.B., Tobita, S., Ito, O. (2004). Drought tolerance characteristics of Brazilian soybean cultivars evaluation and characterization of drought tolerance of various Brazilian soybean cultivars in the field. Plant Production. Science. 7(2): 129-137.

Pimentel, C., Rossielo, R.O.P. (1995). Entendimento sobre relações hídricas. Anais Embrapa. 131-146.

Sant'Anna-Santos, B.F., Silva, L.C., Azevedo, A.A., Aguiar, R. Effects of simulated acid rain on leaf anatomy and micromorphology of Genipa americana L. (Rubiaceae) (2006). Brazilian Archieves of Biology and Technology. 49(2): 313-321.

Santos, R.F., Carlesso, R. (1998). Déficit hídrico e os processos morfológico e fisiológico das plantas. Revista Brasileira de Engenharia Agrícola $e$ Ambiental. 2(3): 287-294.

Sass, J.E. (1951). Botanical Microtechinique. Iowa State College Press, Ames. 228p.
Taiz, L., Zeiger, E. (1991). Plant Physiology. California: The Benjamim/Cummings Publishing Company, Inc., Redwood City.

Turner, I.M. (1994). A quantitative analysis of leaf form in woody plants from the world's major broadleaved forest types. Journal of Biogeography. 21: 413-419.

Wang, W., Vinocur, B., Altman, A. (2003). Plant responses to drought, salinity and extreme temperatures: towards genetic engineering for stress tolerance. Planta. 218: 1-14.

Waldhoff, D., Furch, B., Junk, W.J. (2002). Fluorescence parameters, chlorophyll concentration, and anatomical features as indicators for flood adaptation of an abundant tree species in Central Amazonia: Symmeria paniculata. Environmental and Experimental Botany. 48(3): 225-235.

Received: March 23, 2007; Revised: November 12, 2007; Accepted: November 18, 2008. 